\title{
LETTERS
}

\section{Pregnancy: a test of $\beta$-cell reserve}

Insulin resistance occurs normally in pregnancy to ensure that nutrients are provided to the growing fetus. ${ }^{1-3}$ Pregnancy is considered a test for $\beta$-cell reserve. If there is good function, insulin resistance will be overcome; if not, gestational diabetes will occur.

Lipid deposition in muscle fibres (intramyocellular) could be one of the possible mechanisms of insulin resistance in gestational diabetes mellitus. ${ }^{3,4}$ A poor insulinrelease response, possible fat deposition in the skeletal muscle, or ectopic fat deposition may cause dysfunctional homeostasis in gestational diabetes mellitus, ${ }^{4}$ which may in turn influence the fine tuning of the metabolic machinery of a growing fetus. Offspring may thus be more prone to glucose intolerance and ectopic lipid deposition.

The finding in Blotsky and colleagues' article in CMAJ that children born to mothers with gestational diabetes mellitus are prone to glucose intolerance ${ }^{5}$ may be a sign that the $\beta$-cell function of such children should be monitored.

\section{Dhastagir Sultan Sheriff PhD}

Professor, Reprolabs, Chennai, India

n Cite as: CMAJ 2019 September 3;191:E970. doi: $10.1503 / \mathrm{cmaj} .72557$

\section{References}

1. Ryan EA, Enns L. Role of gestational hormones in the induction of insulin resistance. J Clin Endocrinol Metab 1988;67:341-7.

2. Catalano PM, Huston L, Amini SB, et al. Longitudinal changes in glucose metabolism during pregnancy in obese women with normal gluocose tolerance and gestational diabetes. Am J Obstet Gynecol 1999; 180:903-16.

3. Buchanan TA, Xiang A, Kjos SL, et al. What is gestational diabetes? Diabetes Care 2007;30(Suppl 2):S105-11.

4. Kautzky-Willer A, Krssak M, Winzer C, et al. Intramyocellular lipid concentration identifies impaired glucose metabolism in women with previous gestational diabetes. Diabetes 2003; 52:244-51.

5. Blotsky AL, Rahme E, Dahhou M, et al. Gestational diabetes associated with incident diabetes in childhood and youth: a retrospective cohort study. CMAJ 2019;191:410-7.

Competing interests: None declared. 